\title{
Anti-Trypanosomal Activity of Guiera senegalensis on Trypanosoma brucei Infected Mice
}

\section{Zongo André1,4, Vitouley Sèna Hervé2, Bengaly Zakaria², Kaboré Adama1*, Traoré Aristide³, Tamboura Hamidou Hamadou', Belem Adrien Marie Gaston4.}

${ }^{1}$ Département Productions Animales (DPA) / Institut de l’Environnement et de Recherches Agricoles (INERA), 04 BP 8645 Ouagadoug ou 04, Burkina Faso;

${ }^{2}$ Centre International de Recherche-Développement sur l’Elevage en zone Subhumide (CIRDES), 01 BP 454 Bobo-Dioulasso 01, Burkina Faso;

${ }^{3}$ Institut de Recherche en Sciences de la Sante (IRSS/CNRST) 01 BP 7192 Ouagadougou 01 Burkina Faso;

${ }^{4}$ Institut du Développement Rural (IDR)/Université Nazi Boni, 01 BP 3770 Ouagadougou 01, Burkina Faso.

\begin{abstract}
Aqueous decoction of Guiera senegalensis leaves was studied orally and intraperitoneally for its antitrypanosomal activity on mice infected experimentally with Trypanosoma brucei brucei. After a phytochemical screening followed by an acute toxicity study on mice, the extract of plant was administered once daily for 2 days at doses of 60, 120 and $240 \mathrm{mg} / \mathrm{kg}$ orally and 15, 30 and $60 \mathrm{mg} / \mathrm{kg}$ intraperito neally after infection. Then, parameters of parasitaemia, packed cell volume (PCV), mean survival time and body weight of the mice treated with the extract were measured and compared with positive (diminazene aceturate) and negative (distilled water) controls for 7 days in a row. Results indicate that the aqueous extract of $G$. senegalensis leaves contains tannins, flavonoids, saponosides, reducing compounds and anthocyanosides, alkaloids and coumarins. LD50 of the extract are $1264.49 \mathrm{mg} / \mathrm{kg}$ by oral route and $316.22 \mathrm{mg} / \mathrm{kg}$ by intraperitoneal route. The doses of 240 $\mathrm{mg} / \mathrm{kg}$ by oral route and 15 and $60 \mathrm{mg} / \mathrm{kg}$ by intraperitoneal route of aqueous extract showed a mean survival time (5 days) comparable to the positive control. Parasitaemia level increased in all mice tested except in mice treated with diminazene aceturate during the post-infestation period. During this period, PCV and body weight of all mice decreased by both routes of administration. These results of the study show the pharmacological utility of $G$. senegalensis leaves in the control of TAA by herders / pastoralists and suggest continuing further bio-guided studies to isolate the active components of the plant in order to improve their efficiency.
\end{abstract}

Keywords: In vivo test; Trypanosoma brucei brucei; Guiera senegalensis leaves; phytochemical screening; acute toxicity.

Article Info: Received 18 June 2019; $\quad$ Review Completed 24 July 2019; $\quad$ Accepted 30 July 2019; Available online 15 August 2019

Cite this article as:

André Z, Hervé VS, Zakaria B, Adama K, Aristide T, Hamadou TH, Gaston BAM, Anti-Trypanosomal Activity of Guiera senegalensis on Trypanosoma brucei Infected Mice, Journal of Drug Delivery and Therapeutics. 2019; 9(4-s):273-279 http://dx.doi.org/10.22270/jddt.v9i4-s.3317

*Address for Correspondence:

Kaboré Adama, Département Productions Animales (DPA) / Institut de l'Environnement et de Recherches Agricoles (INERA), 04 BP 8645 Ouagadougou 04, Burkina Faso;

\section{INTRODUCTION}

Parasitic diseases such as African Animal Trypanosomoses (AAT) are one of the impediments to livestock development in sub-Saharan Africa ${ }^{1}$. The fight against TAA includes several strategies including vector control, the use of trypanocidal molecules and the development of vaccines. Vector control with continental programs such as PATTEC (Pan African Tsetse and Trypanosomosis Eradication Campaign) which, in addition to being expensive and laborious, has absolutely not allowed to eradicate tsetse flies like originally planned 2,3 . The use of trypanocidal molecules for prophylaxis (isometamidium chloride) or curative (diminazene aceturate) unfortunately has many cases of trypanosome resistance in more than 18 African countries 4 5, 6. As for the development of vaccines, this strategy is uncertain in the near future 7,8 . In the light of these findings, new researches on the study of the trypanocidal activity of certain medicinal plants commonly used by herders/pastoralists are increasingly being explored ${ }^{9}$.

In Burkina Faso, rural population often uses ancestral knowledge of medicinal plants to treat diseases of humans and animals 10,11. Recent studies conducted in the country's Gaongho Pastoral Zone have shown that farmers extensively use plants to treat animal diseases such as AAT 12. 
Among these plant species, Guiera senegalensis leaves are commonly used and its trypanocidal efficacy in vitro on Trypanosoma brucei brucei has been proven in a previous study ${ }^{13}$. Also, the present study was performed to evaluate the anti-trypanosomal activity in vivo of $G$. senegalensis leaves according to the procedure of the herders against $T . b$. brucei infected mice.

\section{MATERIAL AND METHODS}

\section{Plant material and preparation}

The leaves of the G. senegalensis plant were collected in the pastoral area of Gaongho. The specimen of the plant was identified (Voucher specimen number 5952) at the herbarium of "Centre National de la Recherche Scientifique et Technologique" in Burkina Faso.

The leaves of the plant were dried and powdered to prepare a decoction aqueous extract in accordance with the herders' procedure 13. Briefly, $200 \mathrm{~g}$ of the sample of the plant material was placed in a $2000 \mathrm{ml}$ beaker equipped with a lid in which a volume of $2000 \mathrm{ml}$ of distilled water was added. The mixture was homogenized with a glass rod and then boiled on a hot plate for 1 hour (mechanical stirring with a glass rod was made from time to time). After, the extract was warmed and then filtered by pressing on a fine nylon cloth. Obtained filtrate was then centrifuged at $2000 \mathrm{rpm}$ for 10 minutes. The supernatant was collected and concentrated at a temperature of $45^{\circ} \mathrm{C}$ in a ventilated oven. The concentrated decoction obtained was transferred to freezer jars for freeze-drying in order to carry out phytochemical screening and biological tests.

\section{Experimental animals}

Healthy female NMRI albino mice, weighing 25-30 gm and age of 8 weeks, from the "Centre International de RechercheDéveloppement sur l'Elevage en zone Subhumide (CIRDES)" were used. Animals were kept in polypropylene cages (6 animals per cage) under the same conditions of temperature $\left(25^{\circ} \mathrm{C}\right)$, relative humidity of $70-80 \%$ and $12: 12 \mathrm{~h}$ dark / light cycle with free access to standard diet and tap water ad libitum.

\section{Trypanosome parasite}

The strain of T. b. brucei (reference Farako-ba 80 / CRTA / 01) was provided by the CIRDES where it is stored in nitrogen liquid $\left(-180^{\circ} \mathrm{C}\right)$. This strain was used to conduct the test of the extract antitrypanosomal activity on mice.

\section{Phytochemical Screening}

The extract was subjected to phytochemical screening for the presence of active principles using standard screening method of Ciulei 14 (1982).

\section{Biological tests}

\section{(i) Determination of the acute lethal toxicity}

Determination of the acute lethal toxicity of aqueous extract was carried out using oral and intraperitoneal routes according to the method described by Lorke 15 . In the first phase of the method, nine mice fasted for 12 hours before were randomly divided into three groups of three mice each. Mice from each group received 10, 100 and $1000 \mathrm{mg} / \mathrm{kg}$ body weight of the aqueous extract using syringe gavage for oral route and injection for intraperitoneal route. In the second phase of the method, doses of 1600, 2900, and 5000 $\mathrm{mg} / \mathrm{kg}$ of aqueous decoction were administered to nine mice at the rate of three mice per dose and per route. In parallel, a fourth group of three mice receiving only distilled water was used as a control group in each phase. After administration of the extracts, all mice were kept under observation to determine the signs of toxicity ie all behavioral, neurological or physical changes at each level. These signs were recorded at 4 hours and 24 hours after treatment of the mice with particular attention on the first 4 hours. At the end of the 24-hour follow-up, lethal doses 50 $\left(L_{50}\right)$ were evaluated according to the two routes of administration applied.

\section{(ii) Antitrypanosomal activity Test}

Antitrypanosomal activity test of the aqueous decoction of the leaves of $G$. senegalensis was carried out on mice subjected to two routes of administration (oral and intraperitoneal). For each route of administration, three groups of 6 mice were constituted and submitted to three increasing doses. These doses were obtained from the acute toxicity test which permitted to determine the lethal dose 50 $\left(L_{50}\right)$ of aqueous extract according to each applied administration route (dose 1: [dose 2] / 2, dose 2: [LD50] / 10 and dose 3: [LD 50] x 2). In parallel, two other control groups of 6 mice each were used for comparisons: negative control group (distilled water) and a positive control group (Veriben : diminazene aceturate). The mice of the different groups were distributed in cages for an adaptation period of 7 days (day 7: $\mathrm{d}_{7}$ ) under an average temperature of $25^{\circ} \mathrm{C}$ before being infected on the eighth day (day 8: $\mathrm{d}_{8}$ ) with $T . b$. brucei intraperitoneally. This infection was made with 0.2 $\mathrm{mL}$ of infected mice blood ( $10^{4}$ trypanosomes / $\mathrm{mL}$ ). The treatments of the mice were made on the 3rd day postinfection (day 10: $\mathrm{d}_{10}$ ) when the parasitaemia peak was reached ( $10^{8}$ trypanosomes per $\mathrm{ml}$ of blood). The treatments were applied for two days in a row (day 10 and day 11: $\mathrm{d}_{10}$ and $\mathrm{d}_{11}$ ) with the three increasing doses of the extracts. The positive control group was treated at one time (day 10: $\mathrm{d}_{10}$ ) according to the manufacturer's procedure and the negative control received no treatment. The Antitrypanosomal activity of extract was evaluated using parameters such as parasitaemia, packed cell volume (PCV), body weight and mean survival time of mice.

\section{Determination of parasitemia}

The parasitemia level for each mouse was performed daily ( $d_{8}$ to $d_{15}$ ) by microscopic examination of a drop of blood obtained from the tail tip in triplicates 16 . The fresh blood was placed between slide and coverslip and observed under a microscope at $400 \mathrm{X}$.

\section{Determination of PCV}

PCV was measured every two days $\left(d_{7}, d_{9}, d_{11}, d_{13}\right.$ and $\left.d_{15}\right)$ to indirectly determine the degree of anemia of the mice treated with aqueous extract compared to the control groups. For this, the blood was collected from the tail of each mouse in heparinized capillary tubes which were subjected to centrifugation at $12500 \mathrm{rpm}$ for 5 minutes for a good separation of the constituents. The PCV reading was made using a haematocrit reader expressed in percentage.

\section{Body weight}

Body weight of each mouse per group was recorded daily from $d_{7}$ to $d_{15}$. For this, the mice were weighed individually.

\section{Mean survival time}

This parameter was calculated for each mouse in the treated with plant extract and controls groups throughout the follow-up period by differentiating between the day the mouse dies and the day of treatment.

\section{Statistical analysis}


For the calculation of the $\mathrm{LD}_{50}$, the formula was applied : $L D_{50}=\sqrt{ }\left(D_{0} \times D_{100}\right)$ where $D_{0}$ is the highest dose that causes no mortality and $\mathrm{D}_{100}$ is the lowest dose that produces $100 \%$ mortality 15. The results of the phytochemical screening were noted - (absence) or + (presence). For antitrypanosomal activity test, data obtained were expressed as mean \pm standard deviation of mean of measured parameters and subjected to one-way analysis followed by Tukey's test at $5 \%$ for comparison of the results obtained from different groups.

\section{RESULTS}

\section{Determination of the LD50}

The results of the acute toxicity study of extract are presented in Table 1. The intraperitoneal route presented mice mortality at the dose of $1000 \mathrm{mg} / \mathrm{kg}$ in phase 1 . In contrast, the oral route induced mortality of the mice at the dose of $1600 \mathrm{mg} / \mathrm{kg} \mathrm{PC}$ in phase 2. According to formula of Lorke 15 (1983), the lethal doses 50 (LD 50 ) of the extract tested are $1264.49 \mathrm{mg} / \mathrm{kg}$ by oral route and $316.22 \mathrm{mg} / \mathrm{kg}$ by intraperitoneal route.

Table 1: Acute toxicity effect of $G$. senegalensis leaves aqueous extract administrated orally and intraperitoneal route in mice.

\begin{tabular}{|l|c|c|c|c|}
\hline Phases & Doses $(\mathrm{mg} / \mathrm{kg})$ & \multirow{2}{*}{$\begin{array}{c}\text { Number of } \\
\text { mice used }\end{array}$} & & \multicolumn{2}{|c|}{ Mortality number } \\
\cline { 4 - 5 } & & & Orally route & $\begin{array}{c}\text { Intraperitoneal } \\
\text { route }\end{array}$ \\
\hline Phase 1 & 10 & 03 & 00 & 00 \\
& 100 & 03 & 00 & 00 \\
& 1000 & 03 & 00 & 03 \\
Control & Distilled water & 03 & 00 & 00 \\
Phase 2 & 1600 & 03 & 03 & 03 \\
& 2900 & 03 & 03 & 03 \\
& 5000 & 03 & 03 & 03 \\
\hline
\end{tabular}

\section{Phytochemical Screening}

The phytochemical profile of the extract revealed the presence of phenolic compounds (tannins), saponosides, alkaloids, anthocyanosides, reducing compounds, steroid glycosides, triterpenes, carbohydrates, flavone glycosides and coumarins (Table 2).

Table 2: Phytochemical profile of the aqueous decoction of G. senegalensis

\begin{tabular}{ll}
\hline Chemical groups & $\begin{array}{l}\text { decoction of } G . \\
\text { senegalensis }\end{array}$ \\
\hline Polyphenols (tannins) & ++ \\
saponosides & ++ \\
Alkaloids salts & ++ \\
Reducing compounds & ++ \\
carbohydrates & + \\
anthocyanosides & ++ \\
Steroid glycosides & ++ \\
Triterpene glycosides & ++ \\
Flavone Glycosides & + \\
Anthracénosides & nd \\
Cardiac glycosides & nd \\
Coumarines and derivatives & + \\
\hline
\end{tabular}

++ = abundant; + = not abundant; nd = not detected

\section{In vivo test}

\section{(i) Mean survival time}

Figure 1 show the mean survival time of mice in all groups after the application of treatments compared to the control groups. The mean survival time of the negative control group (distilled water) was one day after the application of the treatment. In contrast, there was an increase in the mean survival time ( 5 days) of mice in the groups treated with the plant extract at the doses of $240 \mathrm{mg} / \mathrm{kg}$ orally and 15 and $60 \mathrm{mg} / \mathrm{kg}$ intraperitoneally and the positive control group (Veriben : Diminazene aceturate).

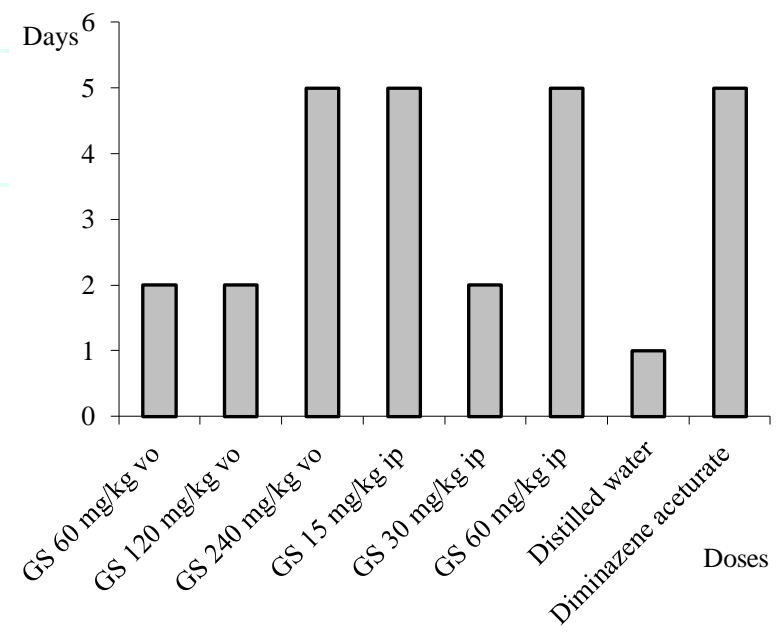

Figure 1: Mean survival time of mice after the treatment application in all groups during the study (GS: G. senegalensis ; vo : oral route ; ip : intraperitoneal route). 


\section{(ii) Parasitemia Level}

Parasitemia levels (in log number / $\mathrm{mL}$ ) in all groups of mice are presented in Figure 2. The mice were parasitized as early as the second day after infection $\left(d_{9}\right)$ and all died at $d_{11}$ in the negative control group (distilled water). The mice were parasitized as early as the second day after infection ( $\left.d_{9}\right)$ and all died on $d_{11}$ in the negative control group. The number of trypanosomes in the blood of mice in all study groups increased over time except in the positive control group where trypanosomes died on the second day of diminazene aceturate administration $\left(d_{11}\right)$. The degree of parasitaemia between the groups treated with the extract at a dose of 240 $\mathrm{mg} / \mathrm{kg}$ orally and those treated with the doses of $15 \mathrm{mg} / \mathrm{kg}$ and $60 \mathrm{mg} / \mathrm{kg}$ intraperitoneally was not significantly different $(\mathrm{p}>0.05)$ during the post-treatment period.

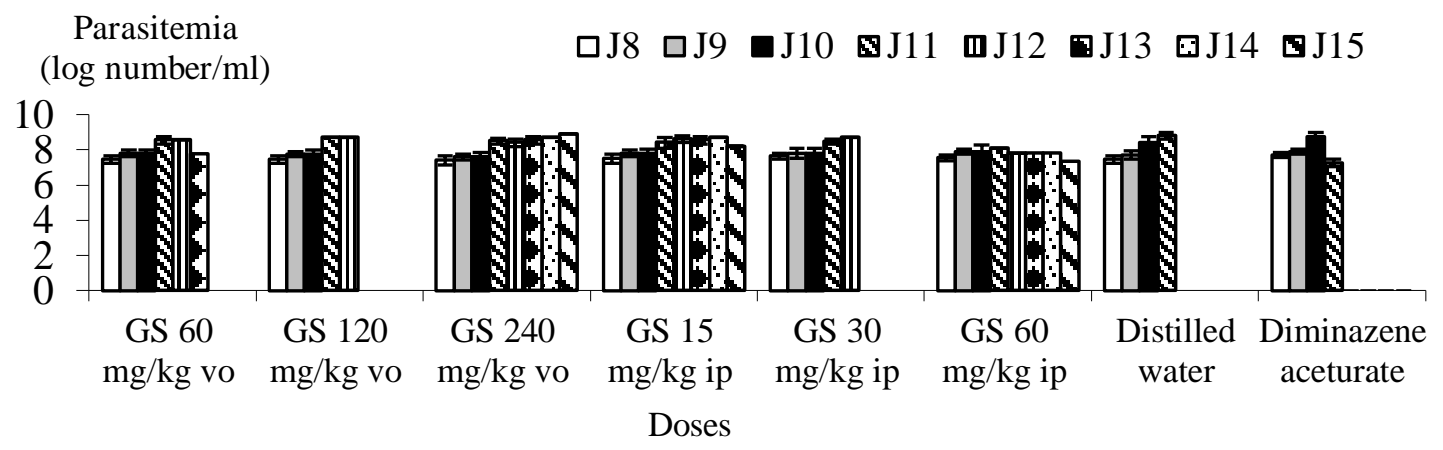

Figure 2: Parasitaemia levels of mice after the treatment application in all groups during the study (GS: G. senegalensis ; vo : oral route ; ip : intraperitoneal route).

\section{(iii) Packed cell volume}

Figure 3 shows the PCV levels of mice in the tested groups. PCV means after the infection of mice decreased from $d_{7}$ to $\mathrm{d}_{15}$ in all groups. These PCV means of mice group treated with diminazene aceturate were higher $(\mathrm{p}<0.05)$ than those of the mice treated with extract at the doses of $240 \mathrm{mg} / \mathrm{kg}$ orally and 15 and $60 \mathrm{mg} / \mathrm{kg}$ intraperitoneally from $\mathrm{d}_{13}$ to $\mathrm{d}_{15}$.

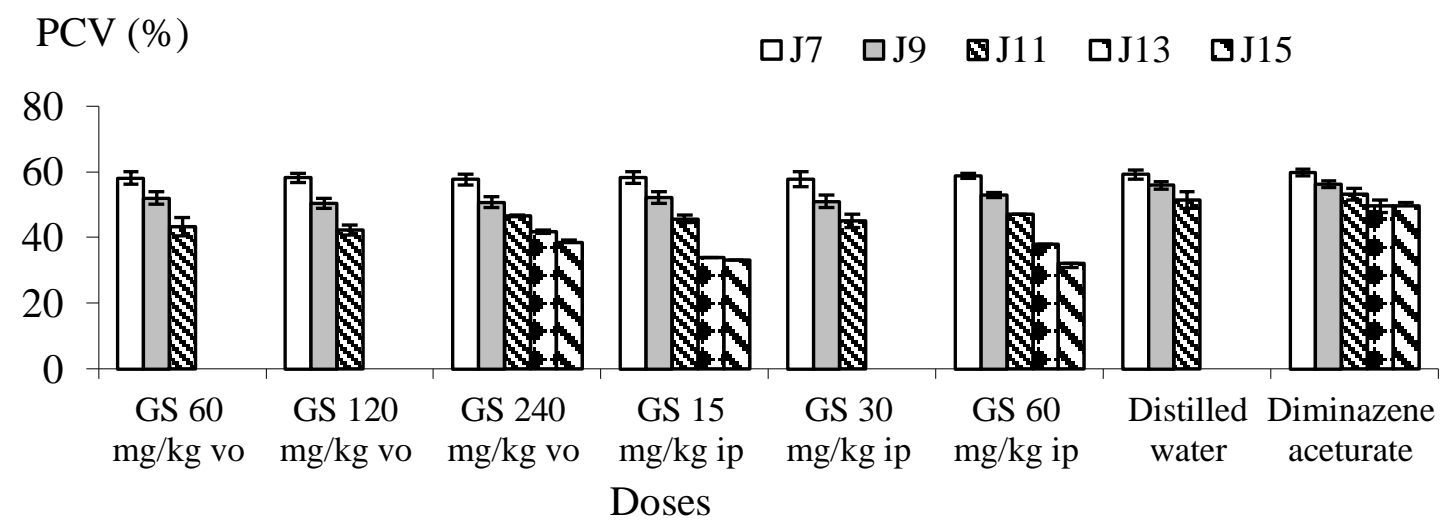

Figure 3: PCV levels of mice after the treatment application in all groups during the study (GS: G. senegalensis ; vo : oral route ; ip : intraperitoneal route).

\section{(iv) Body weight change}

Body weight change of mice at $\mathrm{d}_{7}$ to $\mathrm{d}_{15}$ of experiment is reported in Figure 4. After infection with T. b. brucei, a significant weight decrease $(\mathrm{p}<0.05)$ from $\mathrm{d}_{8}$ to $\mathrm{d}_{15}$ in experimental mice was observed in all groups. This weight loss was more marked $(\mathrm{p}<0.05)$ in the treated groups with oral doses of $240 \mathrm{mg} / \mathrm{kg}(10.08 \%)$ and $60 \mathrm{mg} / \mathrm{kg}(7.61 \%)$ by the oral route. intraperitoneal compared with the groups treated with diminazene aceturate $(4.68 \%)$ and $15 \mathrm{mg}$ $(4.93 \%)$ intraperitoneally. With mice treated with diminazene aceturate, the weight loss was followed by a weight recovery phase starting on $d_{11}$. 


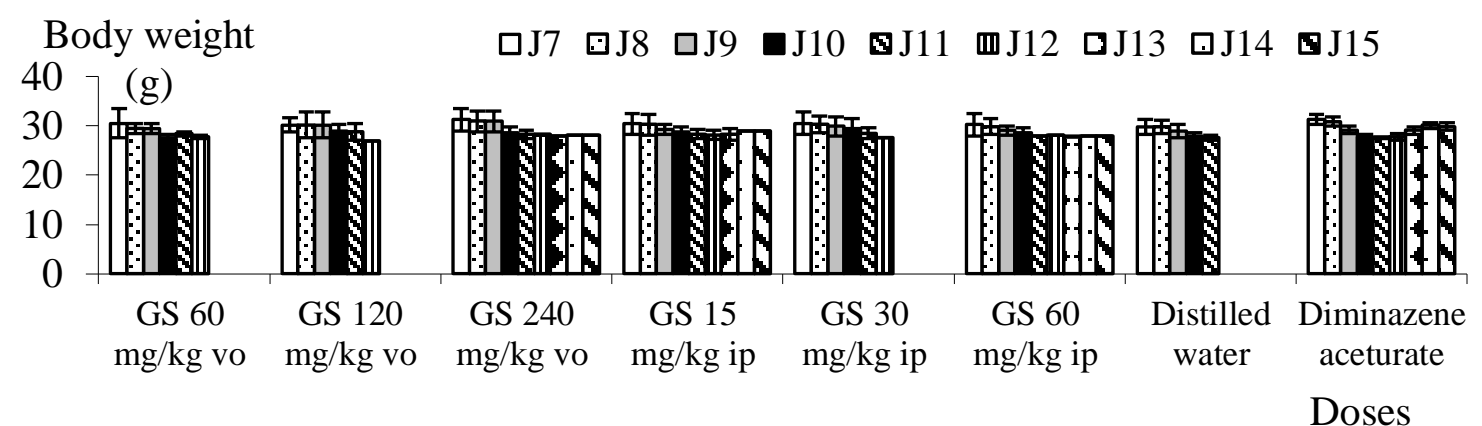

Figure 4: Body weights of mice in mice after the treatment application in all groups during the study (GS: G. senegalensis ; vo : oral route ; ip : intraperitoneal route)

\section{DISCUSSION}

In this study, the efficacy of aqueous decoction of $G$. senegalensis leaves as trypanocidal in mice experimentally infected with a T. brucei brucei strain was tested. This approach aims to explore veterinary ethnomedicine practiced by farmers in rural areas of Africa in the treatment of animal diseases 17. To improve these practices, the study of the toxicity of natural drugs used is very important to determine their safety.

The acute toxicity results of aqueous decoction of $G$. senegalensis leaves in mice have a dose-response effect depending on the administration routes. The LD50 of the extract was $1264.49 \mathrm{mg} / \mathrm{kg}$ orally and $316.22 \mathrm{mg} / \mathrm{kg}$ intraperitoneally. This difference of the LD50 between the two routes of administration corroborates the observations made by Lahlou et al. 18 and Amein et al. 19 with the aqueous extract of Tanacetum vulgare and thymoquinone in mice. The LD50 analysis obtained in our study revealed that the aqueous leaf extract of G. senegalensis is slightly toxic by oral route and moderately toxic by intraperitoneal (IP) route according to the toxicity scale of Hodge and Sterner 20.

Similar results were obtained with the hydro-methanolic root extract of $G$. senegalensis and the infusion of Cassia sieberiana root bark orally by Shettima et al. ${ }^{21}$ and Ajayi et $a{ }^{22}$ respectively. By intraperitoneal route, the results obtained in our study are comparable to those of Fané 23 with the aqueous macerate of $C$. sieberiana root bark in mice, although the two methods of preparation are different. The low toxicity of $G$. senegalensis extract orally in mice confirms its usual use by herders/pastoralists and traditional healers in the treatment of various human and animal diseases, including TAA 12 .

Phytochemical screening of the leaf extract of G. senegalensis revealed several chemical groups with recognized pharmacological activities. These groups are tannins, saponosides, reducing compounds, carbohydrates, anthocyanosides, steroid glycosides, triterpenes, alkaloid salts and coumarins and derivatives. These results are in agreement with those of Kouamé et al. ${ }^{24}$-and Yagana et al. 25 who found tannins, saponosides, carbohydrates, terpenoids, flavonoids and alkaloids in the $G$. senegalensis leaves. Similarly, the presence of coumarins and derivatives obtained in our study confirms the observations of Soulama et al. ${ }^{26}$ who report that natural coumarins are secondary metabolites synthesized by plant leaves. All these chemical groups contained in the extract would have the power to act on one or more target sites associated with a physiological process 27 and to interfere with the redox balance of parasites acting on the respiratory chain or cellular defenses against oxidative stress that partially eliminate trypanosomes 27,28 .

Indeed, flavonoids inhibit the growth of trypanosomes and act on trypomastigote forms found in the bloodstream of mammals 29,30. Similarly, flavonoids from natural plants act as free radicals and metal chelators that inhibit lipid peroxidation and exhibit various physiological activities, including antihypertensives and anti-arthritic activities 31 Alkaloids reduce the growth of trypanosomes by intercalating deoxyribonucleic acid (DNA) with trypanosomes 32 and inhibiting protein synthesis 29 . The anti-trypanosome activity of the phenolic compounds is the inhibition of the alternative trypanosome oxidase enzyme 33. According to Taylor et al. 34-one of the molecular actions of tannins is to complex proteins through so-called non-specific forces such as hydrogen bonding, the hydrophobic effect as well as the covalent bond formation. For terpenes, the mechanisms of trypanocidal activity include the formation of aldehydethiol adducts with sulfur-containing components, thereby decreasing the buffering of agents that can create oxidative stress in the cells 35 and the oxidation of glutathione and pyruvic acids ${ }^{36}$.

After infection of the mice on day 8, a high parasitemia $\left(10^{8}\right.$ trypanosomes per $\mathrm{ml}$ of blood) was observed in all the groups on day 10 followed by mouse mortality between 2 and 7 days. The pre-patent period (2-7 days) of T. b. brucei in the study is different from that (7-11 days) obtained by Bengaly et al. 37 on mice infected with Trypanosoma congolense at a dose of $10^{5}$ trypanosomes $/ \mathrm{mL}$ of blood. The duration of the pre-patent period could then be thought to depend on the parasite strain and the immune status of the infected host, although $T$. congolense generally has a longer pre-patent period than T. brucei. Nevertheless, the survival time of the mice in the study is close to that (5 to 7 days) of Kelly et al. 38 who infected CDI strain mice with T. b. brucei at the dose of 105 trypanosomes (strain 427). Intraperitoneally, an average survival time of 5 days was observed with two doses (15 and $60 \mathrm{mg} / \mathrm{kg}$ ) of the extract tested whereas this survival time was only reached with the dose of $240 \mathrm{mg} / \mathrm{Kg}$ orally. This shows a clear efficiency of the intraperitoneal route compared to the oral route. These results are in phase with those obtained by Benoit-Vical et al. ${ }^{39}$ evaluating Chrozophora senegalensis in the treatment of malaria on mice. According to these authors, this difference could be due to the low bioavailability of the extract administered orally. In fact, the average survival times of the mice infected and treated with the doses of $240 \mathrm{mg} / \mathrm{kg}$ oral and those of 15 and 60 $\mathrm{mg} / \mathrm{kg}$ by intraperitoneal route could be attributed to the activity of the chemical components that the extract contains. This belief is supported by previous studies that 
reveal that polyphenols have the ability to increase the survival of mice infected with $T$. $b$. brucei 40,41 . Similarly, Mergia et al. ${ }^{34}$ revealed that administration of the methanolic extract of Clutia abyssinica resulted in a survival time of $39.20 \pm 0.37$ days in mice infected with Trypanosoma congolense. The survival time of the mice despite increasing parasitemia over time in the study suggests that administration of the extract does not completely eliminate trypanosomes from the blood of infected mice during the study. Several works $42,43,44$ have led to similar observations and concluded that a high parasite load could mask the effectiveness of the crude extracts of the plant 45 . This could be due to the enzymatic inactivation of the phytochemicals that these extracts contain 46 . On the other hand, the pharmacokinetics of the phytochemicals of the tested extract, including their rapid elimination, may also explain the low in vivo efficacy of the decoction ${ }^{47}$. These hypotheses reinforce the observations made because the trypanocidal efficacy in vitro of the aqueous extract of the plant has been proved previously on T. b. brucei with increasing doses of 25,50 and $100 \mathrm{mg} / \mathrm{ml}$ by Zongo et al. ${ }^{13}$. Similar finding is made by Abedo et al. 48 evaluating the trypanosomal activity of methanolic extract of stem bark Gongorenema latifolium on mice infected with Trypanosoma congolense in Nigeria.

After infection of the mice, the PCV level decreased continuously. This could be explained by hemolysis of red blood cells associated with increased parasitemia. Indeed, trypanosome infections cause an increase in the sensitivity of the red blood cell membrane to oxidative damage. Oxygen-generated oxygen reactions released by trypanosomes can also damage red cell membranes and cause haemolysis ${ }^{49}$. The effect of the extract in anemia would be to reduce parasite load while neutralizing the toxic metabolites produced by trypanosomes or by trapping free radicals associated with trypanosomes that could be attributed to the secondary metabolites mentioned above $45,50,41$.

Our results also showed a decrease in mouse weights since their infection with T. b. brucei. This is fully in line with the findings of Alli et al. ${ }^{41}(2011)$ who showed that T. b. brucei was associated with weight loss. This decrease in body weight could also be explained by the drop in the PCV level associated with a high parasitemia level followed by a decrease in appetite. This results in consumption of fat stores and severe degenerative changes in muscle cells and other tissues in the infested host. In addition, there is increased degradation of proteins in the muscles leading to atrophic degeneration. Decreased supply of oxygen can cause anemia and this is also an important factor 51,52 .

\section{CONCLUSION}

The results of this study showed that the decoction of $G$. senegalensis leaves leads to an average survival time of the treated mice comparable to those of the positive control group although they are parasitized. This is probably related to the metabolite substances that the extract contains. Therefore, leaves of $G$. senegalensis could be considered as a potential source for the search for new drugs against TAA. For this purpose, additional studies could be conducted to isolate the active components of the extract to improve the plant anti-trypanosomal activity.

\section{ACKNOWLEDGMENTS}

The authors are grateful to the project FCN $05-2014$ of PPAAO/WAAPP of Burkina Faso for financial support provided.

\section{CONFLICT OF INTEREST}

There is no conflict of interest among the authors.

\section{REFERENCES}

1. Sow A., Sidibe I., Bengaly Z., Bance A.Z., Sawadogo G.J. (2012). Irradiated Male Tsetse from a 40-Year-Old Colony Are Still Competitive in a Riparian Forest in Burkina Faso. PLoS ONE. $7(5)$.

2. Bouyer J., Seck MT., Sall B. (2013). Misleading guidance for decision making on tsetse eradication: Response to Shaw et al. (2013). Prev. Vet. Med. http://dx.doi.org/10.1016/i.prevetmed.2013.05.017.

3. Shaw A.P., Torr S.J., Waiswa C., Cecchi G., Wint G.R., Mattioli R.C., Robinson T.P. (2013). Reply to the letter to the editor by Bouyer et al.. Prev. Vet. Med. 112, 447-449.

4. Delespaux V., Dinka H., Masumu, J., Van den Bossche P., Geerts S. (2008a). Five fold increase in the proportion of diminazene aceturate resistant Trypanosoma congolense isolates over a seven years period in Eastern Zambia. Drug Resist Update 11, 205-209.

5. Vitouley HS., Bengaly Z., Adakal H., Sidibe I., Van Den Abbeele, J., Delespaux, V. (2013). Réseau d'EpidémioSurveillance de la Chimiorésistance aux trypanocides et aux acaricides en Afrique de l'Ouest (RESCAO). Tropicultura. 31, 205-212.

6. Tchamdja E., Kulo A. E., Vitouley H. S., Batawui K., Bankole A. A., Adomefa K., Cecchi G., Hoppenheit A., Clausen P. H., De Deken R., Van Den Abbeele J., Marcotty T., Delespaux V. (2017). Cattle breeding, trypanosomosis prevalence and drug resistance in Northern Togo. Veterinary Parasitology.http://dx.doi.org/10.1016/i.vetpar.2017.02.008

7. Magez S., Radwanska M. (2009). African trypanosomiasis and antibodies: implications for vaccination, therapy and diagnosis. Future Microbiology 4, 1075-1087.

8. Magez S., Caljon G., Tran T., Stijlemans B., Radwanska M. (2010). Current status of vaccination against African trypanosomiasis. Parasitology 137, 2017-2027.

9. Vitouley HS., Bengaly Z., Lapo RA., Gbati, OB., Assane M. (2007). Etude du potentiel trypanocide d'extraits aqueux de plantes médinales pour le traitement de la trypanosomose animale africaine. Revue Africaine de Santé et de Productions Animales. 5, 9-15.

10. Ouedraogo S., Belemnaba L., Traore A., Lompo M., Bucher B.Guissou I.P. (2008). Etude de la toxicite et des proprietes pharmacologiques de l'extrait aqueux de anogeissus leiocarpus (dc) guill. et perr (combretaceae). Pharmacopée et médecine traditionnelle africaines. $15: 18-22$

11. Centre for Analysis of Economic and Social Policy (CAPES) (2006). Inventory of local knowledge in Burkina Faso. Inventory of good practices and proposals for their contribution to development. Ouagadougou. 448 pages.

12. Zongo A., Kaboré A., Traoré A., Zabré G., Traoré A., Tamboura H. H., Belem A. M. G. (2017a). Constraints of Ruminant Rearing and Ethno-veterinary Practice Against African Animal Trypanosomosis in the Pastoral Area of Gaongho in Burkina Faso. Animal and Veterinary Sciences. 5(1): 1-7. Doi: 10.11648/j.avs.20170501.11.

13. Zongo A., Kaboré A., Bengaly Z., Vitouley H.S., Traoré A., Tambora H.H., Belem.A.M.G. (2017b). Prevalence of trypanosoma brucei brucei and potential in vitro trypanocidal activity of aqueous extracts of some medicinal plants in the pastoral area of gaongho in Burkina Faso. J. Anim. Health Prod. 5(3): 107-114.

14. Ciulei I. (1982). Methodology for analysis of vegetable drug. Practical manual on industrial utilization of medicinal and aromatic plants, Bucharest, Ministry of Chemical industry, 67 pages.

15 Lorke D. (1983). A new approach to practical acute toxicity testing. Arch. Toxicol. 54: 275-287.

16. Herbert WJ, Lumsden WHR (1976). Trypanosoma brucei: A rapid "matching"method for estimating the host's parasitemia. Experiment. Parasitol. 40: 427-431.

17. Bâ A. S. (1996). Passé, présent et perspectives de l'ethnomédecine vétérinaire africaine. Rev. sci. tech. Off. int. Epiz. 15 (3), 813-826.

18. Lahlou S., Israili Z., Lyoussi B. (2008). Acute and chronic toxicity of a lyophilized aqueous extract of Tanacetum vulgare leaves in rodents. J. Ethnopharmacol. 117: 221-227. 
19. Amein A., Alkhawajah A.,A., Randhawa M. A., Sheikh N.A. (2008). Oral and intraperitonéale LD50 of thymoquinone, an active principle of Nigella sativa in mice and rats. J. Ayub. Med. Coll. Abbottabad., 20(2): 25-27.

20. Hodge HC., Sterner JH. (1943). Determination of substances acute toxicity by LDB50B. Amer. Industrial Hyg. Assoc. 10: 93.

21. Shettima Y.A., Tijjani M.A., Karumi Y., Sodipo O. A. (2012). Phytochemical and anti-diarrhoeal properties of methanol root extract of Guiera senegalensis J.F.Gmel. Inter. Tes. J. Pharmacy, 3 (11): 61- 65.

22. Ajayi C. O., Elujoba A. A., Bejide R. A., Akinloye J. A., Omonisi A. E. (2015). Toxicity and Pharmacognostic Standards for Laxative Properties of Nigerian Cassia sieberiana and Senna obtusifolia Roots. European Journal of Medicinal Plants. 6(2): 110-123.

23. Fané S., (2003). Etude de la toxicité de certaines plantes vendues sur les marchés du district de Bamako. Thèse de Pharmacie. Université de Bamako, Mali, 153 pages.

24. Kouamé J., Gnoula C., Palé E., Bassolé H., Guissou IP., Simporé J., Nikiéma JB. (2009). Etude des propriétés cytotoxiques et antiradicalaires d'extraits de feuilles et de galles de Guiera senegalensis J. F. Gmel (Combretacae). Science et technique, Sciences de la santé. 32 (1-2): 9-23.

25. Yagana S., A., Sodipo O. A., Yagana K., Modu S. (2012) Antibacterial activities of the extracts of the roots of Guiera senagalensis J.F.Gmel. J. Pharm. BioMed Sci., 23: 1-7.

26. Soulama S., Nacoulma O. G., Meda R. N., Boussim J. I., MillogoRasolodimby J. (2013). Teneurs en coumarines de 15 ligneux fourragers du Burkina Faso. Int. J. Biol. Chem. Sci. 7(6): 22832291.

27. Maikai V. A. (2011). Antitrypanosomal activity of flavonoid extracted from Ximenia Americana stem bark. Int J. Biol. 3(1):115-121.

28. Wurochekke AU., Anyanwu GO., (2012). Antitrypanosomal activity of Anogeissus leiocarpus in rats infected with Trypanosoma brucei brucei . Int. Res. J. Biotechnol. 3(1):5-9.

29. Camacho MD. Mata R., Castaneda P., Kirby GC., Warhurst DC., Croft SL., Phillipson JD. (2000). Bioactive compounds from Celaenodendron mexicanum. Planta Med. 66, 463-468.

30. Grecco SS., Reimão JQ., Tempone AG., Sartorelli P., Romoff P., Ferreira MJP., Fávero OA., Lago JHG. (2010). Isolation of an antileishmanial and antitrypanosomal flavanone from the leaves of Baccharis retusa DC. (Asteraceae). Parasitol. Res. 106, 1245-1248.

31. Hoet S., Opperdoes F., Brun R., Quetin-Leclercq J. (2004). Natural products active against African trypanosomes: a step towards new drugs. Nat Prod Rep 21: 353-364.

32. Atawodi S., E., Bulus T., Ibrahim S., Ameh D. A., Nok A. J., Mamman M., Galadima M. (2003). In vitro trypanocidal effect of methanolic extract of some Nigerian Savannah plants. African Journal of Biotechnology. 2 (9), pp. 317-321

33. Yabu Y., Yoshida A., Suzuki T., Nihei C., Kawai K. (2003). The efficacy of ascofuranone in a consecutive treatment on Trypanosoma brucei brucei in mice. Parasitol Int, 52: 155-164.

34. Mergia E., Shibeshi W., Terefe G., Teklehaymanot T. (2014). Evaluation of In vivo Antitrypanosomal Activity of Aqueous and Methanol Leaf Extracts of Clutia abysinica (Euphorbiaceae) against Trypanosoma congolense Field Isolate. Nat. Prod. Chem. Res. 2:138.

35. Nibret E., Wink M. (2010) Volatile components of four Ethiopian Artemisia species extracts and their in vitro antitrypanosomal and cytotoxic activities. Phytomedicine. 17: 369-374.

36. Saeidnia S., Gohari A.R., Uchiyama N., Ito M., Honda G. (2004). Two new monoterpene glycosides and trypanocidal terpenoids from Dracocephalum kotschyi. Chem. Pharm. Bull. 52: 1249-1250.

37. Bengaly Z., Ganaba R., Sidibe I., Sawadogo L., (2002) Comparative pathogenicity of three genetically distinct types of Trypanosoma congolense in cattle: Clinical observations and haematological changes. Veterinary Parasitology. 108(1):1-19.

38. Kelly JM., Quack G., Miles MM. (2001). In Vitro and In Vivo Activities of Aminoadamantane and Aminoalkylcyclohexane Derivatives against Trypanosoma brucei. Antimicrobial Agents Chemotherapy. 45 (5):1360-1366

39. Benoit-Vical F., Soh Njommang P., Saléry M., Harguem L., Poupat C., Nongonierma R., (2008). Evaluation of Senegalese plants used in malaria treatment: Focus on Chrozophora senegalensis. Journal of Ethnopharmacology. 116:43-48

40. Ngure RM., Ongeri B., Karori S.M., Wachira W., Maathai RG., Kibugi JK., Wachira, FN. (2009). Antitrypanosomal effects of Azadirachta indica (neem) extract on Trypanosoma brucei rhodesiens -infected mice. Engl. J. Med. 14: 2-9.

41. Alli L. A., Okochi V. I., Adesoken A.A. (2011). Antitrypanosomal activity and hematological effects of aqueous extract of leaves of Morinda Lucida on Trypanosoma brucei brucei infected rats. Asian J pharm hea Sci 1: 111-115.

42. Wurochekke A.U., Nok A.J. (2004). In vitro and in vivo antitrypanosomal activity of the leaf of Lawsonia inermis against Trypanosoma brucei brucei infection in mice. J Medical Sci. 4: 236-239.

43. Ibrahim H., Ogbadoyi E., Adamu K., Bello M., Yemisi I. (2012). Evaluation of antitrypanosomal activity of ethyl acetate extract of Adansonia digitata seed extract in T. b. brucei infected albino mice. Int J Drug Res Tech, 2: 454-460.

44. Ogbadoyi E., Adamu Y., Omotosho R. (2011) Preliminary studies of the antitrypanosomal activity of Garcinia kola nut extract in mice infected with T. b. brucei. Journal of Medicine and Medical Sciences. 2: 628-631.

45. Ekanem JT., Kolawole OM., Abbah OC. (2008). Some biochemical and haematological effects of black seed (Nigella sativa) oil on Trypanosoma brucei infected rats. Afr J Biochem Res 2: 79-85.

46. Mann A., Egwim EC., Banji B., Abdukadir N., Gbate M. (2009). Efficacy of Dissotis rotundifolia on Trypanosoma brucei brucei infection in rats. Afr. J. Biochem. Res. 3: 5-8.

47. Williams S., Saha L., Singha U.K., Chaudhuri M. (2008). Trypanosoma brucei: differential requirement of membrane potential for import of proteins into mitochondria in two developmental stages. Exp Parasitol. 118: 420-433.

48. Abedo J. A., Jonah O. A., Abdullahi R. S., Mazadu M. R., Idris H. Y., Muhammed H., Shettima F. T., Ombugadu S., Daudu M., Garba J., Abdulmalik U., Kugu B. A., Usman A. O., (2013). Evaluation of trypanosomal activity of Tapinanthus globiferus and Gongronema latifolium on Trypanosoma congolense. Bioscience Research. 10(1): 20-28.

49. Albert M., Hussein K. (2012). The Mechanisms of anemia in trypanosomiasis: A Review, Anemia, Dr. Donald Silverberg (Edition).

50. Inabo H.I., Fathuddin MM. (2011). In vivo antitrypanosomal potentials of ethyl acetate leaf extracts of Punica granatum against T. b. brucei. Advances in Agricultural biotechnology. 1: 82-86.

51. Holmes P.H., Katunguka-Rwakishaya E., Bennison J.J., Wassink G.J., Parkins J.J. (2000). Impact of nutrition on the pathophysiology of bovine trypanosomiasis. Parasitology. 120: 73-85.

52. Tatli Z. A. (2004). Chemical Constituents of Verbascum L. Species FABAD. J. Pharm. Sci. 29: 93-107. 